Урош В. Шуваковић ${ }^{1}$,

УДК 050:316СОЦИОЛОШКИ ПРЕГЛЕД"1938/2018"

Универзитет у Београду

Уводник

Учитељски факултет

Примљен 28/10/2018

Катедра за филозофију и друштвене науке

Прихваћен 29/10/2018

Главни и одговорни уредник Социолошкої ӥреїлеgа

Београд (Србија)

doi: $10.5937 /$ socpreg52-19306

\title{
ДВЕСТОТИ БРОЈ
}

Поштовани читаоци,

Пред Вама је двестоти број нашег часописа. Некако се десило да ово буде година јубилеја: навршило се осамдесет година од изласка првог броја Социолошкоі̄ йреілеga 1938. године, а сада је бр. 3/2018 истовремено и укупно двестоти број часописа. Свесни смо да традиција не служи само свечарењу, већ и да обавезује. Стога настојимо да подигнемо квалитет часописа и предузимамо неопходно да он буде доступан читаоцима широм Земље, тако што сваки чланак објављујемо, осим на српском језику ћириличким писмом, и на енглеском језику.

У овом броју налазе се радови из тематски различитих области социологије, сврстаних у четири блока: први садржи предметно веома хетерогене радове, други се односи на питања криминологије у најширем смислу - што сматрамо веома важним пошто је последњих година број радова који се бавио питањима из области ове дисциплине мали, а несумњив је научни закључак да је транзиција, укључујући и ону у Србији, довела до повећања стопе криминалитета. Стога би било логично да криминолошка истраживања добију и у научном и у друштвеном погледу на значају. Тој теми ћемо настојати да и убудуће посветимо више пажње. Следи тематски блок посвећен односима образовања/васпитања и друштва. Ту се показује тенденција која је у потпуној супротности са оном претходном која се односи на криминологију. Радова који се баве, са аспекта наше науке или мултидисциплинарно, образовањем и васпитањем све је више, што је вероватно последица динамичности образовног процеса и значајних реформских промена које се у том сегменту друштва одвијају. Коначно, последњи блок представљају осврти на значајне књиге које су објављене у скорије време. И ту се држимо традиције и недостижног узора из првог броја Социолошкої ӥреїлеgа из 1938, када су у једном броју објављени кратки прикази више од сто осамдесет универзитетских уџбеника, научних монографија, научних часописа и посебних чланака за које је тадашња редакција оценила да су значајни за сазнање о социологији као науци у Краљевини Југославији (Uređivački odbor, 1938, str. 321-436). Такав подухват је тешко поновити, поред осталог и зато што је научна политика у Србији таква да се прикази научних радова (а предложено је за убудуће - ми се надамо да неће бити усвојено - и осврти, научне критике

1 uros-s@eunet.rs 
и научне полемике) не сматрају никаквим доприносом науци, иако баш критички приказ неког дела представља његову научну валоризацију. То за последицу има да је, за разлику од 1938, веома тешко пронаћи писце приказа, па наша академска јавност остаје ускраћена чак и за елементарну информацију - а камоли критички однос - према новим издањима. Ипак, садашња редакција је прекинула ћутање о новим књигама и из броја у број објављује по неколико осврта и приказа, не само традиције ради, већ и због свести о научном и друштвеном значају да књиге не остану прећутане.

Оцењујући да је први број Социолошкої ӥреїлеgа из 1938. постао део научне и културне баштине наше земље, као и да су текстови у њему публиковани и данас релевантни не само са аспекта историје науке, посебно не само са аспекта историје српске социологије, Српско социолошко друштво - као издавач - у сарадњи са Институтом друштвених наука, Београд као суиздавачем, а уз техничку подршку ЈП Завод за уџбенике, Београд, објављује у овој години јубилеја фототипско издање првог броја нашег часописа, са пратећом опремом, које су приредили проф. др Јовица Тркуља и проф. др Урош Шуваковић. Пошто финансијска средства за такве пројекте обично недостају, истичемо да је наше обраћање пренумерантима уродило плодом пошто су они ти који су обезбедили скоро половину потребних средстава за ову књигу, која ће изаћи из штампе вероватно истовремено са овим бројем часописа. Остатак средстава обезбеђен је захваљујући разумевању Министарства просвете, науке и технолошког развоја Републике Србије. Редакција Социолошкоі üреiлеga се нада да ће она стићи до руку што већег броја социолога, али и припадника других струка, с обзиром на изразито мултидисциплинарну оријентацију коју је имало Уредништво часописа (Uređivački odbor, 1938, str. 3-10) објављујући његов први број.

У години обележавања осамдесет година од изласка првог броја нашег часописа, најављујемо и публиковање монографског анотираног издања Социолошки üpeĩлeg 1938-2018: Библиоірабија, што предвиђамо за прве месеце 2019. године. Желимо да тиме припадницима научне заједнице олакшамо упознавање са радовима објављеним у часопису. 
Uroš V. Šuvaković ${ }^{1}$, University of Belgrade, Teacher Education Faculty

Department of Philosophy and Social Sciences

Editor-in-chief of Sociološki pregled/Sociological Review

Belgrade (Serbia)

\title{
THE TWO-HUNDREDTH ISSUE
}

\author{
(Translation In Extenso)
}

Dear Readers,

The two-hundredth issue of our journal is now before you. It somehow happened that this year holds multiple anniversaries: eighty years have passed since the first issue of Sociološki pregled/Sociological Review was published in 1938, and now the issue no. 3/2018 is also the two-hundredth issue of the journal. We are aware that the purpose of tradition is not only to celebrate, but also to oblige. Therefore, we strive to raise the quality of the journal and take necessary measures to make it available to readers all over the world by publishing each article not only in Serbian, in Cyrillic script, but also in English.

This issue holds papers belonging to thematically different areas of sociology, divided into four parts: the first one contains very heterogeneous papers in terms of the subject matter, the second one deals with the issues of criminology in the broadest sense - which we consider very important as the number of papers dealing with these issues within the field of this discipline has been small in recent years, but it is an indubitable scientific conclusion that transition, including the one in Serbia, has led to an increase in the crime rate. Therefore, it would be logical for the scientific and social importance of criminological research to be increased. We will strive to pay more attention to this topic in the future. The thematic part that follows is on relations between education \& society. The tendency here is completely opposed to the one that relates to criminology. The work on education and upbringing, from the aspect of our science or in a multidisciplinary way, is increasing, which is probably due to the dynamics of the educational process and the significant reform changes that have been taking place in that segment of society. Finally, the last part is dedicated to opinion reviews of important books that have been published recently. Here as well, we stick to tradition and the unattainable example of the first issue of Sociološki pregled/Sociological Review from 1938, when short reviews of over one hundred eighty university textbooks, scientific monographs, scientific journals and special articles that the then editorial board considered important for knowledge about sociology as science in the Kingdom of Yugoslavia were published in one issue (Uređivački odbor, 1938, pp. 321-436). Such an undertaking is difficult to repeat, among other things, because the scientific policy in Serbia is such that book's reviews (it was proposed for

1 uros-s@eunet.rs 
the future - hopefully not adopted - opinion/ reviews, scientific critiques and scientific discussions) are not considered to be a contribution to science, although the very critical review of a piece of work represents its scientific valorization. This results in the fact that, unlike in 1938, it is very difficult to find authors of book's reviews, so our academic public remains deprived of even elementary information - let alone a critical attitude - towards new editions. However, the current Editorial Board has interrupted the silence about new books and published a number of book's reviews, not only for the sake of tradition, but also for the awareness of the scientific and social importance that the books do not remain without response.

Judging that the first issue of Sociološki pregled/Sociological Review from 1938 became a part of the scientific and cultural heritage of our country, and that the texts published in it are still relevant not only from the aspect of the history of science, in particular not only from the aspect of the history of Serbian sociology, the Serbian Sociological Association - as the publisher - in cooperation with the Institute of Social Sciences, Belgrade, as the co-publisher, and with the technical support of the Serbian State Publisher of Textbooks, Belgrade, in this anniversary year publishes a phototype edition of the first issue of our journal, with the accompanying material, edited by professors Jovica Trkulja, PhD and Uroš Šuvaković, PhD. Since financial resources for such projects are usually lacking, we emphasize that our appeal to subscribers has been fruitful since they have provided almost half of the necessary funds for this book, which will leave the press probably at the same time with this issue of the journal. The rest of the funds was provided thanks to the understanding of the Ministry of Education, Science and Technological Development of the Republic of Serbia. The Editorial Board of Sociološki pregled/ Sociological Review hopes that it will reach the attention of a growing number of sociologists and members of other professions in view of a highly multidisciplinary orientation that the editorial board of the first issue (Uređivački odbor, 1938, pp. 3-10) had at the time of its publication.

In the year of marking eighty years since the first issue of our journal, we also announce the publication of the monograph Sociološki pregled/Sociological Review 19382018: Bibliography, which is planned during the first months of 2019. We want to make it easier for members of the scientific community to get informed with the papers published in the journal.

\section{REFERENCES / ЛИTEPATУРA}

Uređivački odbor (1938). Introduction. Sociološki pregled vol. 1, 3-10. Beograd: Društvo za sociologiju i društvene nauke. Available at http://www.socioloskipregled.org.rs/ category/brojevi/1938/

Uređivački odbor (1938). Sociological Textbooks \& Critical Review of Books. Sociološki pregled vol. 1, 321-436. Beograd: Društvo za sociologiju i društvene nauke. Available at http://www.socioloskipregled.org.rs/category/brojevi/1938/ 